\title{
Genetic background analysis of pseudoexfoliation syndrome in Polish population - summary overview
}

\section{Analiza podłoża genetycznego zespołu pseudoeksfoliacji w populacji polskiej - podsumowanie}

\author{
Grażyna Malukiewicz', Hanna Lesiewska', Joanna Stafiej', Katarzyna Linkowska², \\ Jacek Swobodziński², Tomasz Grzybowski²
Department of Ophthalmology Nicolaus Copernicus University, Collegium Medicum, Bydgoszcz, Poland Head: Professor Grażyna Malukiewicz, MD, PhD
Head: Professor Tomasz Grzybowski, MD, PhD \\ 2 Institute of Forensic Medicine, Department of Molecular and Forensic Genetics
}

\begin{abstract}
Ahstract: $\quad$ Aim: To evaluate Contactin Associated Protein-Like 2 (CNTNAP2), Contactin-Associated Protein-Like 4 (CNTNAP4), Lysyl Oxidase-Like Protein 1 (LOXL1) and superoxide dismutase 1 (SOD1) gene polymorphisms in patients with pseudoexfoliation syndrome (PEX).

Material and methods: The study group consisted of 73 cataract patients with PEX and 111 controls with cataract but without PEX. Blood samples were obtained from each participant via peripheral venepuncture and genomic DNA was isolated according to the standard procedures. Genotypes of the CNTNAP4 esv12669 was determined using a commercially available assay. Previously reported chosen gene polymorphisms assessed by us in PEX patients were overviewed.

Results: There was no difference in both allele and haplotype frequencies of single-nucleotide polymorphisms (SNPs) in CNTNAP2 (rs2107856 and rs214138) and in SOD1 (rs10432782 and rs2070424) between PEX patients and controls. There was no difference in in frequencies of copy-number variations (CNVs) alleles esv12669 in the CNTNAP4 and esv11910 in the CNTNAP2 between PEX patients and controls. There were significant associations between PEX and SNPs in LOXL1- for the G allele of rs3825942 ( $p=0.0047$ ) and for the T allele of rs216541 ( $p=0.021)$. The haplotype (GGT) consisting of all three risk alleles was significantly overrepresented $(87.5 \%)$ in patients with PEX.

Conclusions: our studies confirm a genetic basis for PEX with the significant association between the assessed LOXL1 SNPS and PEX in Polish population.

Key words: $\quad$ Pseudoexfoliation syndrome, PEX, gene polymorphisms, Polish population, CNTNAP, LOXL1, SOD1.

Abstrakt: $\quad$ Cel: Celem pracy było określenie polimorfizmów genów kodujących białka oddziałujące z kontaktyną 2 i 4 (CNTNAP2, CNTNAP4), oksydazę lizylową 1 (LOXL1) i dysmutazę ponadtlenkowej (SOD1) u chorych z zespotem pseudoeksfoliacji (PEX).

Materiat i metoda: Grupę badaną stanowiło 73 chorych z zaćmą i zespołem pseudoeksfoliacji, a grupę kontrolną 111 osób z zaćmą bez PEX. Od każdego badanego pobierano krew. DNA izolowano z wykorzystaniem standardowych procedur. Polimorfizm CNTNAP4 esv12669 określano przy pomocy komercyjnego zestawu. W pracy omówiono również badane przez nas poprzednio u chorych z PEX polimorfizmy wybranych genów.

Wyniki: nie stwierdzono różnic w częstości alleli i genotypów dla SNP w genie CNTNAP2 (rs2107856 and rs214138) i SOD1 (rs10432782 and rs2070424) pomiędzy grupą pacjentów z PEX a grupą kontrolną. Nie stwierdzono również różnic pomiędzy grupą badaną i kontrolną w częstościach alleli dla polimorfizmów liczby kopii (CNV): esv12669 w genie CNTNAP4 i esv11910 w genie CNTNAP2. Stwierdzono istotną statystycznie zależność między występowaniem zespołu PEX a SNPs genu LOXL1: rs3825942 dla allelu $G(p=0,0047)$ oraz rs216541 dla allelu T ( $p=0,021)$. Haplotyp (GGT) składający się z trzech alleli ryzyka istotnie częściej występował u chorych z zespołem PEX (87.5\%).

Wnioski: Nasze badanie potwierdza genetyczne podłoże zespołu PEX z istnieniem istotnej zależności pomiędzy zespołem PEX a jednonukleotydowymi polimorfizmami genu LOXL1 w polskiej populacji.

Słowa kluczowe: zespół pseudoeksfoliacji, PEX, polimorfizm genów, populacja polska, CNTNAP, LOXL1, SOD1.

The authors declare no conflict of interest/ Autorzy zgłaszają brak konfliktu interesów w związku z publikowaną pracą
\end{abstract}

\section{Introduction}

Pseudoexfoliation syndrome (PEX) represents a complex, multifactorial, age-related disease of worldwide significance and often associated with elevated intraocular pressure. The average prevalence of PEX is $10-20 \%$ of the general population over the age of 60 years (1). The incidence of PEX varies among ethnic groups (2). Genetic and nongenetic factors are known to be involved in the etiopathogenesis of PEX. Some evidence 
exists for the contribution of the genes with relatively small effects, e.g. clusterin (CLU), apolipoprotein E (APOE), glutathione S-transferases (GSTs), and tumor necrosis factor-alpha (TNFA), in certain study populations (3). Three single nucleotide polymorphisms (SNPs) in the lysyl oxidase-like 1 gene (LOXL1) have been shown to be associated with PEX $(1,4,5,6)$. Krumbiegel et al. showed that APOE genotypes are not associated with PEX in either Germans or Italians (7). Some studies suggest an association between PEX and two SNPs, rs2107856 and rs2141388, of the CNTNAP2 contactin-associated protein-like 2 gene. This correlation was observed in German patients; however, it was not evident in an Italian cohort $(8,9)$. Interestingly, it was shown that some SNPs of CNTNAP2 and CNTNAP4 genes are associated with aging and age-related disorders such as Alzheimer's and Parkinson's diseases $(10,11)$

There is increasing evidence that oxidative stress is invoIved in the pathobiology of PEX. Polymorphisms in genes encoding antioxidant enzymes may result in reduced enzyme activity and increased levels of reactive oxygen species $(12,13)$.

In this study we evaluated the CNTNAP4, contactin-associated protein-like 4 gene, and current findings concerning the association between the chosen SNPs of LOXL1, CNTNAP2, and SOD1 gene polymorphisms in PEX.

\section{Materials and methods}

We studied 73 patients and 111 age-matched control subjects who presented to the Department of Ophthalmology Collegium Medicum UMK in Bydgoszcz for cataract surgery. Patients were enrolled in the study, if they had no other ocular or systemic disease (e.g. glaucoma, age related macular degeneration - AMD, diabetes, dyslipidemia, hypertension, mental health disorders) except for cataract and PEX. The diagnosis of PEX was confirmed in each case by a thorough slit lamp examination. Pseudoexfoliation changes were identified as the presence of typical PEX material on the anterior surface of the lens, iris, or corneal endothelium in either eye. Controls were individuals without any evidence of pseudoexfoliation deposits on intraocular tissues and no evidence of any systemic disease. The participants gave their informed written consent for enrolment. The study protocol was approved by the Ethical Committee of Collegium Medicum in Bydgoszcz.

Genomic DNA was extracted from blood samples collected from patients and controls according to the standard procedures. Esv11910 in CNTNAP2 gene and Esv12669 in CNTNAP4 gene were investigated. Genomic DNA was isolated using GeneMatrix Bio-Trace DNA Purification Kit according to the manufacturer's protocols (Eurx). DNA quantity was assessed by real time quantitative PCR using a ViiA ${ }^{\text {TM }} 7$ Real-Time PCR System (Life Technologies). Since lakubov et al. have found that the "at risk" variants are del/del for Esv12669 in the CNTNAP4 gene and for Esv11910 in CNTNAP2 gene the presence of ins allele, regular PCR is enough to discriminate between the presence of the insertion (ins/ins or ins/del) or its absence (del/del) $(10,11)$. Variants of each CNVs were determined using a ViiA ${ }^{\text {TM }}$ 7 Real-Time PCR System (Life Technologies) following the manufacturer's instructions. Each PCR sample contained $10 \mu \mathrm{l}$ of GoTaq ${ }^{\circledR}$ qPCR Master Mix (Promega), $1.8 \mu \mathrm{l}$ of each primer (final concentration of $900 \mathrm{nM}$ for each primer) $2 \mu \mathrm{l}$ of the DNA,
$0.2 \mu \mathrm{l} \mathrm{CXR}$ and $4.2 \mu \mathrm{l}$ of PCR-grade water. The amplification conditions were: $2 \mathrm{~min}$ at $95^{\circ} \mathrm{C}, 40$ cycles of $15 \mathrm{sec}$ at $95^{\circ} \mathrm{C}$ each, followed by 1 minute at $60^{\circ} \mathrm{C}$. Primer sequences for the esv12669 in the CNTNAP4 gene and esv11910 in CNTNAP2 gene are provided in Table I.

\begin{tabular}{|c|l|}
\hline \multicolumn{1}{|c|}{ Primer } & \multicolumn{1}{c|}{ Sequence } \\
\hline Primer Forward cnv12669_F & 5'TGCAACACAAAGGGAGTTCCT3' \\
\hline Primer Reverse cnv12669_R & 5'GCAGATAAGGGAGAGTGAGTGACA3' \\
\hline Primer Forward cnv11910_F & 5'CCCGATCAATGCAAATTCTATTT3' \\
\hline Primer Reverse cnv11910_R & 5'GGGCCAGCACCTGAAGCT3' \\
\hline
\end{tabular}

Tab. I. Primer sequences for the CNV analysis of esv12669 in the CNTNAP4 and esv11910 in the CNTNAP2.

Tab. I. Sekwencje starterów wykorzystanych w analizie wariantów liczby kopii esv12669 (gen CNTNAP4) oraz esv11910 (gen CNTNAP2).

The Fisher exact test was performed to compare possible associations between CNV allele frequency and disease status in patients and controls. Odds ratios were also calculated. The significance level for all statistical tests was 0.05 . Statistical analysis was performed using Statistica software (version 8).

Genotypes of the LOXL1 SNPs: rs1048661 (R141L), rs3825942 (G153D), rs2165241, CNTNAP2 SNPs: rs2107856, rs214138 and SOD1 SNPs: rs10432782, rs2070424 were determined using a commercially available assays, as described before $(4,9,13)$.

\section{Results}

There were no differences in frequency of CNTNAP4 esv12669 del/del variant and CNTNAP2 esv11910 del/del variant between PEX group and controls (Tab. II).

\begin{tabular}{|l|c|c|c|c|c|}
\hline & $\begin{array}{c}\text { Subjects } \\
\mathbf{n}(\%)\end{array}$ & $\begin{array}{c}\text { Controls } \\
\mathbf{n}(\%)\end{array}$ & OR & $\mathbf{9 5 \%} \mathbf{C l}$ & $\boldsymbol{P}$ value \\
\hline CNTNAP4 & $27(34)$ & $52(47)$ & 0.6547 & $\begin{array}{c}0.3575- \\
1.1988\end{array}$ & 0.1748 \\
\hline esv12669 & & & & \\
\hline CNTNAP2 & $53(73)$ & $77(70)$ & 1.1357 & $\begin{array}{c}0.5891- \\
2.1895\end{array}$ & 0.7417 \\
\hline
\end{tabular}

Tab. II. Frequencies of CNTNAP4 esv12669 del/del and CNTNAP2 esv11910 del/del variants in PEX patients and controls in the Polish population.

Tab. II. Częstości wariantów esv12669 del/del (gen CNTNAP4) oraz esv11910 del/del (gen CNTNAP2) u pacjentów z PEX oraz w grupie kontrolnej populacji polskiej

Result summary for our previous studies are presented in table III.

\section{Discussion}

\section{Association between LOXL1 and PEX}

LOXL1 belongs to extracellular copper-requiring enzymes which promote collagen and elastin cross-linking. Genome-wide association studies in the Icelandic and Swedish populations 


\begin{tabular}{|c|c|c|c|c|c|}
\hline \multirow{2}{*}{ SNP ID } & Gene & Allele & \multicolumn{2}{|c|}{ Allele frequency } \\
\cline { 3 - 6 } & & & Subjects & Controls \\
\hline rs10432782 & SOD1 & G & 0.19 & 0.18 \\
\hline rs2070424 & SOD1 & G & 0.10 & 0.13 & 0.875 \\
\hline rs1048661 & LOXL1 & T & 0.097 & 0.20 & 0.090 \\
\hline rs38255942 & LOXL1 & A & 0.00 & 0.13 & $0.005^{*}$ \\
\hline rs2165241 & LOXL1 & C & 0.12 & 0.35 & $0.002^{*}$ \\
\hline rs2107856 & CNTNAP2 & T & 0.28 & 0.35 & 0.365 \\
\hline rs2141388 & CNTNAP2 & T & 0.28 & 0.35 & 0.365 \\
\hline
\end{tabular}

* statistically significant $(\mathrm{p}<0.05)$

Tab. III. Allele frequencies of selected genes in patients with PEX and controls in the Polish population.

Tab. III. Częstości alleli wybranych genów u pacjentów z PEX oraz w grupie kontrolnej populacji polskiej.

identified multiple SNPs from the LOXL1 gene which were strongly associated with PEX (6). The same observations were confirmed for other populations: American, Irish, Scottish, English, Finish, Maltese, Indian and Japanese $(1,5)$. In our previous study, we confirmed a significant association of allele $\mathrm{G}$ of rs3825942 (p $=0.0047)$ and allele $T$ of $r s 216541(p=0.021)$ with PEX. The allele frequencies for rs $1048661 \mathrm{G}$, rs $3825942 \mathrm{G}$ and rs2165241 T were slightly higher in our subjects $(0.90 ; 1 ; 0.87)$ than controls $(0.8 ; 0.87 ; 0.65)$. The haplotype (GGT) consisting of all three risk alleles was significantly overrepresented (87.5\%).

\section{No association between CNTNAP2 and PEX}

CNTNAP2 is a large gene on chromosome 7. This gene encompasses almost $1.5 \%$ of chromosome 7 and is one of the largest genes in the human genome. It is little known about specific function and regulation of CNTNAP2. It has been suggested as a candidate gene for various neuropsychiatric disorders $(10,14)$. It encodes for contactin-associated protein-like 2, a neuronal membrane protein and member of the neurexin superfamily (15). Krumbiegel et al. revealed two SNPs, rs 2107856 and rs 2141388, located in intron 11 of the CNTNAP2 gene which were strongly associated with PEX in the German but not the Italian cohort (8). Despite this report, we were unable to show association between the CNTNAP2 SNPs (rs2107856, rs214138) gene and PEX syndrome in Polish patients, as presented in our previous paper (9). These results are in harmony with results for Italian and Japanese cohorts (16). However, the risk that these two SNPs confer to the disease, with an OR of about 1.4, corresponds to the data of Krumbiegel et al. for the German population and is typical of many susceptibility variants identified in complex diseases (8).

The prevalence of clinical exfoliation syndrome increases with age, particularly in the population above the age of 60 (5). Aging is a biological process strongly determined by genetics. A few single nucleotide polymorphisms (SNPs) have been reported to be consistently associated with aging. The study of lakoubov et al. showed that CNTNAP2 in general, and its esv11910 del/del in particular, are associated with healthy aging in humans relative to the current mean life expectancy. Our study did not identify any association between the CNTNAP2 esv11910 CNV and PEX syndrome in Polish patients.

\section{No association between CNTNAP4 and PEX}

A new association with systemic diseases and limited survival past 80 years was recently reported for a copy number variation (CNV) in the CNTNAP4 gene from the neurexin superfamily (10). lakoubov et al. have demonstrated associations between the CNTNAP4 gene and its esv12669 del/del polymorphic variant and longevity, healthy aging, as well as age-related pathologies such as cognitive impairment and, tentatively, Alzheimer's and Parkinson's diseases (11). We analyzed the association between CNTNAP4 esv12669 polymorphism with PEX and found no correlation with this disease.

\section{No association between SOD1 and PEX}

Many studies have shown possible involvement of oxidative stress in the pathogenesis of PEX $(12,17)$. Superoxide dismutase (SOD) is one of the crucial enzymes providing the first line of antioxidant defense which prevents free radical formation. The encoded isozyme is a soluble cytoplasmic protein, acting as a homodimer to convert naturally occurring but harmful superoxide radicals to molecular oxygen and hydrogen peroxide so changes in the activities of this enzyme, can lead to reduced protection against oxidative stress (18). Uçakhan et al. revealed higher activity of SOD in the anterior segment ocular tissue of PEX patients (17). In our previous study, we demonstrated an increased erythrocyte SOD1 activity in PEX patients compared with those without PEX. We analyzed the association between SOD1 rs10432782 and rs2070424 polymorphisms with the risk of PEX, demonstrating that neither was associated with an increased risk of PEX (13).

\section{Conclusion}

To conclude, our studies confirm a genetic basis for PEX, as the significant association between the assessed LOXL1 SNPS and PEX was found in the Polish population. However, they showed no association between CNTNAP2, CNTNAP4, SOD1 SNPs or CNVs and PEX.

The statistical power of presented studies was weak due to relatively small sample sizes, which is why further studies searching for genetic factors contributing to PEX are required. The identification of PEX-associated SNPs would be desirable, as it will enable early detection of PEX-glaucoma, even before the onset of elevated IOP. 


\section{References:}

1. Ramprasad VL, George R, Soumittra N, Sharmila F, Vijaya L, Kumaramanickavel G: Association of non-synonymous single nucleotide polymorphisms in the LOXL1 gene with pseudoexfoliation syndrome in India. Mol Vis. 2008;14:318-322.

2. Challa P, Schmidt $S$, Liu $Y$, Qin $X$, Vann RR, Gonzalez $P$, et al.: Analysis of LOXL1 polymorphisms in a United States population with pseudoexfoliation glaucoma. Mol Vis. 2008; 14:146-149.

3. Schlötzer-Schrehardt U: Genetics and genomics of pseudoexfoliation syndrome/glaucoma. Middle East Afr J Ophthalmol. 2011;18:30-36.

4. Malukiewicz G, Lesiewska-Junk H, Linkowska K, Mielnik M, Grzybowski T, Sulima N: Analysis of LOXL1 single nucleotide polymorphisms in Polish population with pseudoexfoliation syndrome. Acta Ophthalmol. 2011;89:64-66.

5. Tanito M, Minami M, Akahori M, Kaidzu S, Takai Y, Ohira A, et al: LOXL1 variants in elderly Japanese patients with exfoliation syndrome /glaucoma, primary open-angle glaucoma, normal tension glaucoma, and cataract. Mol Vis 2008; 14:1898$-1905$.

6. Thorleifsson G, Magnusson KP, Sulem P, Walters GB, Gudbjartsson $\mathrm{DF}$, Stefansson $\mathrm{H}$, et al.: Common sequence variants in the LOXL1 gene confer susceptibility to exfoliation glaucoma. Science. 2007;317:1397-1400.

7. Krumbiegel M, Pasutto F, Mardin CY, Weisschuh N, Paoli D, Gramer $\mathrm{E}$, et al.: Apolipoprotein $\mathrm{E}$ genotypes in pseudoexfoliation syndrome and pseudoexfoliation glaucoma. J Glaucoma. 2010;19:561-565.

8. Krumbiegel M, Pasutto F, Schlotzer-Schrehardt U, Uebe S, Zenkel M, Mardin CY, et al:: Genome-wide association study with DNA pooling identifies variants at CNTNAP2 associated with pseudoexfoliation syndrome. Eur J Hum Gen. 2011;19:186-193.

9. Malukiewicz G, Lesiewska-Junk H, Linkowska K, Grzybowski T, Kaźmierczak K: Analysis of CNTNAP2 polymorphisms in Polish population with pseudoexfoliation syndrome. Acta Ophthalmol. 2012;90:660-661.
10. lakoubov L, Mossakowska M, Duan Z, Sesti F, Puzianowska-Kuznicka M: A Common Copy Number Variation (CNV) Polymorphism in the CNTNAP4 Gene: Association with Aging in Females PLOS One. 2013;8:79790.

11. lakoubov L, Mossakowska M, Szwed M, Puzianowska-Kuznicka M: A common copy number variation polymorphism in the CNTNAP2 gene: sexual dimorphism in association with healthy aging and disease. Gerontology. 2015;61:24-31.

12. Yağci R, Gürel A, Ersöz I, Keskin UC, Hepşen IF, Duman S, et al.: Oxidative stress and protein oxidation in pseudoexfoliation syndrome. Curr Eye Res. 2006;31:1029-1032.

13. Lesiewska H, Malukiewicz G, Linkowska K, Grzybowski T: Analysis of SOD1 polymorphisms in Polish population with pseudoexfoliation syndrome. Acta Ophthalmol. 2015;93:322-323.

14. Friedman JI, Vrienhoek T, Markx S, Janssen IM, van der Vliet WA, Faas $\mathrm{BH}$, et al.: CNTNAP2 gene dosage variation is associated with schizophrenia and epilepsy. Mol Psychiatry. 2008;13:261$-263$.

15. Poliak S, Gollan L, Martinez R, Custer A, Einheber S, Salzer JL, et al.: Caspr2, a new member of the neurexin superfamily, is 10calized at the juxtaparanodes of myelinated axons and associates with K+channels. Neuron. 1999;24:1037-1047.

16. Shimizu A, Takano $Y$, Shi D, Yokokura $S$, Yokoyama $Y$, Zheng $X$, et al.: Evaluation of CNTNAP2 gene polymorphisms for exfoliation syndrome in Japanese. Mol Vis. 2012;18:1395-1401.

17. Uçakhan 00, Karel F, Kanpolat A, Devrim E, Durak I: Superoxide dismutase activity in the lens capsule of patients with pseudoexfoliation syndrome and cataract. J Cataract Refract Surg. 2006;32:618-622.

18. Zhang Y, Zhang L, Sun D, Li Z, Wang L, Liu P: Genetic polymorphisms of superoxide dismutases, catalase, and glutathione peroxidase in age-related cataract. Mol Vis. 2011;17:2325-2332.

The paper was originally received 24.03.2019 (KO-00196-2019)/ Praca wpłynęta do Redakcji 24.03.2019 (KO-00196-2019) Accepted for publication 12.04.2019/ Zakwalifikowano do druku 12.04.2019

Reprint requests to (Adres do korespondencji):

Hanna Lesiewska

Department of Ophthalmology, Nicolaus Copernicus

University, Collegium Medicum in Bydgoszcz,

Sklodowskiej-Curie 9, 85-094 Bydgoszcz, Poland

e-mail: hanjot@op.pl

Tel/fax: 48525854033 